\title{
PRELIMINARY REPORT ON STRATIGRAPHY OF KENAI GROUP, UPPER COOK INLET, ALASKA
}

By D. C. Hartman, G. H. Pessel, D. L. McGee

Special Report No. 5

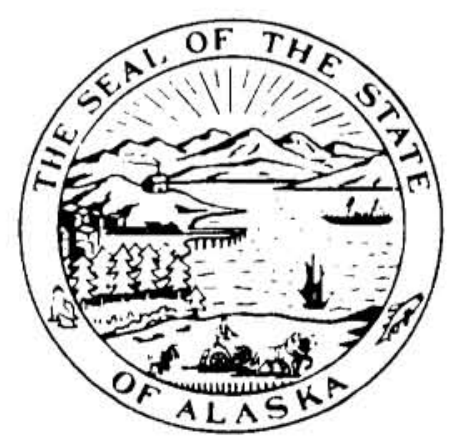

DIVISION OF GEOLOGICAL SURVEY

DEPARTMENT OF NATURAL RESOURCES

STATE OF ALASKA

July 1972 
STATE OF ALASKA

DEPARTMENT OF NATURAL RESQURCES

DIVISION OF GEOLOGICAL SURVEY

PRELIMINARY REPORT

KENAI GROUP OF COOK INLET, ALASKA

By

D. C. Hartman, G. H. Pessel, \& D. L. McGee

November 1971 


\section{ILLUSTRATIONS}

Plate 1..........Stratigraphic Correlation Section AA', Northern Kenai Peninsula.

Plate 2.........Stratigraphic Correlation Section B8', Northern Kenai Peninsula.

Plate 3..........Stratigraphic Correlation Section CC', Northern Kenai Peninsula.

Plate 4..........Stratigraphic Correlation Section D ', Northeastern Cook Inlet Basin.

Plate $5 . . . . . .$. lsopach, West Foreland Formation.

Plate 6......... Isopach, Hemlock Conglomerate \& Bell Island Sandstone.

Plate 7.......... Isopach, Tyonek Formation.

Plate $8 \ldots . . . .$. Isopach, Beluga Formation.

Plate 9.......... Isopach, Quaternary plus Sterling Formation.

Plate 10........ Isopach, Total Kenai Group \& Quaternary. 


\author{
PRELIUII:ARY REPORT \\ KENAI GROUP OF COOK INLET BASIN, ALASKA
}

\title{
INTRODUCTION
}

The Cook Inlet Besin in southcentral Aleske is e northeast-trending intermountain trough about $200 \mathrm{miles}$ long and 60 miles wide, bounded on the northwest by the southern Alaska Range and the Castle Mountain fault, and on the southeest by the Chugach Mountains. The basin is filled with about 20,000 cubic miles of Tertiary Kenai Group sediments containing known recoverable reserves of at least 1.5 billion barrels of oll and 3.5 trillion cubic feet of gas (Kirschner, 1971). Exploration for new reserves is continuing.

This preliminary report is a summery interpretation of presently-known stratigraphy of the Kenai Group (early middle Tertiary to Quaternary age) In the north-central part of the basin, where nearly all cook Inlet wells have been drilled. As seismic intormation is not available to the State, detailed subsurface structure cannot be incorporated in this report, which is intended to be a guide to areas containing types and thicknesses of Kenai rocks most favorable for oil and gas exploration.

\section{STRATIGRAPHY}

\section{General}

The Kenai Group is more than 20,000 feet thick in the deepest parts of Cook Inlet Basin, and is divided into five formations as proposed by Calderwood and Fackler (Bull. AAPG, v. 56, \#4); named from oldest to youngest the West Foreland Formation, Hemlock Conglomerate, Tyonek Formation, Beluga Formation, and Sterling Formation. In this study, strata of Quaternary age are included with the Sterling formation due to uncertainty in determining their contact.

Using limited outcrop and locally abundant well data, an isopach map has been made for each formation of the Kenai Group, as well as for the total thickness of the Group. These maps show thickness penetrated by wells uncorrected for dip.

\section{West Foreland Formation}

West Foreland strata were distributed widely over the basin upon an undulating erosional surface of Mesozoic and early Tertiary rocks, probably by stream and current action in a shallow estuarine environment. Volcanics are present in wells near Trading Bay, but more typical are interbedded siltstones, tuffaceous claystones, sandstones, and conglomerates with a few coal beds. There is some possibility that outerops of conglomerate and tuff south of Capps Glacier (up to 3500 feet thick) may be equivalent to West Foreland, but they were not mapped as such in this report. Oil production from the West Foreland is presently limited to sands in the McArthur River field, where cumulative production is about 6,000,000 barrels. 
Hemlock Conglomerate (and Beil Island Sendstone)

The Hemlock Conglomerate is spread rather evenly over a wide area of the basin, averaging about 600 feet thick, and appears to be a fluvial-deltaic deposit of pebbly sandstone with minor siltstone. It is the major oilproducing unit of Cook Inlet Basin at the Swanson River, Middle Ground Shoal, McArthur River, and Trading Bey tields, and is oil-saturated but not economically producible at the Granito Point tiula. Tho sourco aroa oppears to bo from the north, probably from the ancestral Susitna River. Cumulative Hemlock oil production approximates $315,000,000$ barrels to date.

The Bell Island Sandstone, although frequently considered a member of the Tyonek Formation, is correlated here with the Hemlock, and isopachs of both units are presented on a single map. Both these sandy units occur at the base of the Tyonek section and overlie the West Foreland Formation with a roughly comparable thickness. Bell Island Sands are distinctly finer and siltier than Hemlock, and isopachs suggest a more northeasterly source. A cross-basin ridge may have separated the two units into contemporary sub-basins. With the exception of some nonproducible oil saturation in the Union "Pittman" well near Wasilla, no oil or gas has been produced from the Bell Island Sandstone.

\section{Tyonek Formation}

More than 7000 feet of fluvial, deltaic, and estuarine deposits comprising the Tyonek Formation were laid down in the basin trough following Hemlock deposition. Abundant channel and floodplain sands and conglomerates with silt and coal occur to the northwest, forming major oil reservoirs at the Middle Ground Shoal, MoArthur River, Trading Bay, and Granite Point fields. Large gas reserves are present at the Kenai field. To date, oil production from Tyonek beds is about 69,000,000 barrels, with gas production amounting to about 83 billion cubic feet.

The formation grades laterally to predominant sandy siltstone, claystone, and coal to the northeast, southeast, and south, with a few sands apparently coming in from the eastern margin of the basin. These eastern sands have been found to be barren of oil or gas to date.

\section{Beluga Formation}

Following Tyonek deposition and probable slight local folding of the basin floor, a thick series of alternating thin sands, silts, and coals of the Beluga Formation was lald down in a pair of basinal depressions. The main source of sediments was apparently from the north, as in Tyonek deposition, with continued channel-sand deposits to the northwest, but erosion of the uplifted Chugach range supplied conglomeratic sediments to a developing basin in the Deep Creek and Sterling areas as well. Important gas production comes from Beluga sands at the Beluga River and North Cook Inlet fields, where a total of some 56 billion cubic feet have been produced.

\section{Sterling Formation}

As much as 10,000 feet of thick-bedded Sterling Formation and Quaternary sandstone was deposited in central and eastern Cook Inlet Basin during late Tertiary - early Quaternary time, with major sediment sources from both the 
Chugach range and Alaska range, which were being uplifted strongly at this time. This depositional phase, mooitied by Quaternary to Recent glacial scour and recession, has left the basin essentially in its present state.

Lower Sterling sands are major gas reservoirs at the Swanson River, Beaver Creek, Kenai, Beluga River, and Nortn Cook Inlet fields. Cumulative production is over 330 billicion cubic teet.

SUMMARY AND CONCLUSIONS

A set of six isopach maps accompanies this report, showing the form and approximate extent of the various formations of trie Konai Group in Cook Inlet Basin, and also the relation of productive fields to thickness.

In general, producing fields are arrayed along the flanks of the thicker deposits of each formation, suggesting origin of hydrocarbons in the deeper parts of the basin and subsequent migration toward the shallower areas.

Three major areas of the basin appear to be relatively untested: 1) An eastern basin flanking the Chugach range was active during Hemlock, and again during Beluga and Sterling deposition; this area may be prospective for both oll and gas. Unfortunately, it is also involved in the proposed Kenai Wilderness withdrawal. 2) A possible eastern edge line is indicated for the Hemlock Conglomerate, trending roughly southeastward from Beshta Bay, passing several miles east of Swanson River, and heading toward the Skilak Lake area. Both of these prospective areas will depend on favorable structure for commercial oil or gas accumulations. 3) Lower Cook Inlet, southwest of Kalgin Island, is virtually untested, due malnly to existing Iitigation as to ownership between the Federal and State governments. There are, then, large areas of the Cook Inlet Basin that are quite prospective for important new oil and gas reserves. 


\section{REFERENCES}

1. KIrschner, C. E., \& Lyon, C. A., "Stratigraphic and Tectonic Development of the Cook Inlet Petroleum Province". Paper, Arctic Symposium, San Francisco, Calif., 4 Feb. 1971.

2. Calderwood, K. W., \& Fackler, W. C., "Proposed Stratigraphic Nomenclature for the Kenal Group, Cook Inlet Basin, Alaska". Bull. A.A.P.G., v. 56, \#4, April 1972. 